\title{
PERSEPSI KEBERMANFAATAN, KEMUDAHAN DAN KEPUASAN WAJIB PAJAK ORANG PRIBADI DALAM PENGGUNAAN E-FILING SEBAGAI SARANA PELAPORAN SPT TAHUNAN SECARA ELEKTRONIK \\ (Studi pada Dosen dan Pegawai Universitas Pendidikan Ganesha Tahun 2017)
}

\author{
Ni Luh Putu Rosy Bilyantari1, Made Ary Meitriana1, Anjuman Zukhri2 \\ Jurusan Pendidikan Ekonomi, Fakultas Ekonomi \\ Universitas Pendidikan Ganesha Singaraja, \\ Indonesia
}

e-mail : rosybilyantari26@gmail.com1, ary.meitriana@undiksha.ac.id1, anjumanzukhri@undiksha.ac.id2

\begin{abstract}
Abstrak
Penelitian ini bertujuan untuk mengetahui persepsi kebermanfaatan, persepsi kemudahan dan persepsi kepuasan wajib pajak orang pribadi dalam penggunaan sistem e-filing sebagai sarana pelaporan SPT Tahunan secara elektronik. Jenis penelitian ini adalah penelitian deskriptif, populasi dalam penelitian ini adalah dosen dan pegawai Universitas Pendidikan Ganesha yang berstatus sebagai pegawai negeri sipil berjumlah 680 orang dan sampel sebanyak 87 orang. Data dikumpulkan dengan metode dokumentasi dan kuesioner, analisis data yang digunakan adalah analisis deskriptif. Hasil penelitian menunjukkan bahwa persepsi kebermanfaatan wajib pajak orang pribadi dalam penggunaan sistem e-filing dikategorikan sangat bermanfaat dengan total skor sebesar 4202, persepsi kemudahan wajib pajak orang pribadi dalam penggunaan sistem e-filing dikategorikan mudah dengan total skor sebesar 2881 dan persepsi kepuasan wajib pajak orang pribadi dalam penggunaan sistem e-filing dikategorikan sangat puas dengan total skor sebesar 2565.
\end{abstract}

Kata kunci : e-filing, persepsi kebermanfaatan, persepsi kemudahan, persepsi kepuasan.

\begin{abstract}
The purposes of this study was aimed at knowing the perception of the usefulness, the perception of the convenience and the perception of satisfaction of individual taxpayers in the use of e-filing system as an electronic annual SPT reporting tool. The kind of this study was descriptive study, the populations of this study were lecturers and stafs of Ganesha University of Education who have status as civil servants numbered 680 peoples and samples numbered 87 peoples. The data were collected by using documentation and questionnaire method, the data analysis used was descriptive analysis. The result of study showed that the perception of the usefulness of individual taxpayers in the use of e-filing system was categorized very useful with the total score 4202, the perception of convenience of individual taxpayers in the use of e-filing system was categorized easy with the total score 2881 and the perception of satisfaction of individual taxpayers in the use of e-filing system was categorized very satisfied with the total score 2565 .
\end{abstract}

Keywords: e-filing, perception of usefulness, perception of convenience, perception of satisfaction. 


\section{PENDAHULUAN}

Pajak merupakan salah satu sumber pendapatan bagi negara, dimana pajak tersebut digunakan oleh pemerintah untuk pembiayaan pembangunan nasional dan untuk mensejahterakan masyarakat. Menurut Undang-Undang Nomor 16 Tahun 2009, "pajak adalah kontribusi wajib kepada negara yang terutang oleh orang pribadi atau badan yang bersifat memaksa berdasarkan undang-undang dengan tidak mendapatkan imbalan secara langsung dan digunakan untuk keperluan negara bagi sebesar-besarnya kemakmuran rakyat". Pengertian pajak menurut Rochmat Soemitro (dalam Mardiasmo (2011:1) "pajak adalah iuran rakyat kepada kas negara berdasarkan Undang-Undang dengan tidak mendapat jasa timbal yang langsung dapat ditunjukkan dan yang digunakan untuk membayar pengeluaran umum negara". Berdasarkan pengertian tersebut dapat disimpulkan bahwa pajak adalah suatu kewajiban yang bersifat memaksa orang pribadi atau badan untuk memberikan iuran kepada kas negara berdasarkan peraturan perundang-undangan yang diberlakukan oleh negara dan hanya digunakan untuk menutup pengeluaran umum negara. Menurut Pandingan (2014:20), "wajib pajak dapat dibedakan menjadi tiga jenis, yaitu wajib pajak orang pribadi, wajib pajak badan dan bendahara". Wajib Pajak Orang Pribadi adalah semua orang yang telah memperoleh penghasilan, yaitu penghasilan yang merupakan objek pajak dan dikenakan tariff umum yang jumlahnya di atas Penghasilan Tidak Kena Pajak (PKTP). Wajib Pajak Badan adalah sekumpulan orang atau modal yang merupakan kesatuan, baik yang melakukan usaha, maupun yang tidak melakukan usaha, yang meliputi perseroan terbatas, perseroan komanditer, perseroan lainnya, badan usaha milik negara atau badan usaha milik daerah, dengan nama dan dalam bentuk apapun. Bendahara adalah pejabat yang ada dalam satuan kerja di instansi pemerintah atau lembaga negara yang ditunjuk pimpinannya dengan Surat Keputusan untuk melaksanakan tugas kebendaharaan.

Fungsi pajak menurut Mardiasmo (2011) terdiri dari dua yaitu, fungsi budgetair dan fungsi mengatur (regulerend). Fungsi budgetair berarti pajak sebagai sumber dana bagi pemerintah untuk membiayai pengeluaran-pengeluarannya. Sedangkan menurut fungsi mengatur (regulerend) berarti pajak sebagai alat untuk mengatur atau melaksanakan kebijaksanaan pemerintah dalam bidang sosial ekonomi. Selain dua fungsi pajak di atas, menurut Sari (2013) pajak juga memiliki tiga fungsi lain. Pertama, fungsi stabilitas, dengan adanya pajak pemerintah memiliki dana untuk menjalankan kebijakan yang berhubungan dengan stabilitas harga sehingga inflasi dapat dikendalikan. Kedua, fungsi redistribusi pendapatan, pajak yang sudah dipungut oleh negara akan digunakan untuk membiayai semua kepentingan umum, termasuk juga untuk membiayai pembangunan sehingga dapat membuka kesempatan kerja, yang pada akhirnya akan dapat meningkatkan pendapatan masyarakat. Ketiga, fungsi demokrasi, pajak yang sudah dipungut oleh negara merupakan wujud gotong royong. Fungsi ini dikaitkan dengan tingkat pelayanan pemerintah kepada masyarakat pembayar pajak.

Direktorat Jenderal Pajak (DJP) sebagai lembaga pemungut pajak di Indonesia telah menerapkan self assessment system dalam pemungutan pajak. Menurut Resmi (2011:18) "self asessment system adalah sistem pemungutan pajak yang memberikan wewenang kepada para wajib pajak untuk menghitung,memperhitungkan, membayar dan melaporkan sendiri pajak yang harus dan telah dibayar melalui suatu Surat Pemberitahuan (SPT)". Surat Pemberitahuan (SPT) adalah surat yang oleh wajib pajak digunakan untuk melaporkan perhitungan dan atau pembayaran pajak, objek pajak dan atau badan objek pajak, dan atau harta dan kewajiban sesuai dengan ketentuan peraturan perundang-undangan perpajakan. Surat Pemberitahuan (SPT) 
Tahunan adalah surat pemberitahuan untuk satu tahun pajak (Resmi, 2007).

Sejak tahun 2011 Pelaporan Surat Pemberitahuan (SPT) dapat dilakukan dengan dua metode, yaitu metode manual dan metode online (e-filing). Pelaporan Surat Pemberitahuan (SPT) secara manual masih dinilai banyak memiliki kekurangan, karena wajib pajak harus melampirkan dokumen (hardcopy) kepada Kantor Pelayanan Pajak, sementara proses perekaman dalam melengkapi data memakan waktu yang cukup lama sehingga pada pelaporan Surat Pemberitahuan (SPT) menjadi tidak efisien. Selain itu, penggunaan Surat Pemberitahuan (SPT) manual dapat terjadi kesalahan (human error) dalam proses ulang perekaman data secara manual oleh aparatur pajak.

E-filing (elektronic filing) merupakan aplikasi (software) yang dibuat untuk digunakan oleh wajib pajak dalam pelaporan Surat Pemberitahuan (SPT) (www.pajak.go.id). Dibuatnya suatu sistem pelaporan pajak secara online dengan menggunakan sistem e-filing dapat memudahkan wajib pajak orang pribadi dalam melaporkan Surat Pemberitahuan (SPT)nya, wajib pajak dapat melaporkan Surat Pemberitahuan (SPT) 24 jam selama 7 hari, hal ini wajib pajak dapat melaporkan Surat Pemberitahuan (SPT)nya meskipun itu pada hari libur. Sistem ini sangat bermanfaat untuk wajib pajak yang tidak melaporkan Surat Pemberitahuan (SPT)nya dengan alasan sibuk, selain itu dengan adanya sistem $e$ filing ini dapat mengurangi biaya yang ditimbulkan dari penggunaan kertas.

Adanya sistem e-filing diharapkan dapat menjadi sarana yang lebih bermanfaat dan menguntungkan bagi wajib pajak dikarenakan dalam pelaporan Surat Pemberitahuan (SPT)nya lebih sederhana, kemudahan dalam penggunaan sistem e-filing membuat wajib pajak tidak membutuhkan waktu lama untuk mempelajari teknologi ini karena fitur dan menu yang disediakan jelas dan mudah dipahami, dan dengan adanya sistem e-filing diharapkan bisa memberikan kepuasan bagi wajib pajak karena pelaporan pajak menjadi lebih efektif dan efisien.

Penerapan sistem e-filing sebagai suatu teknologi yang tidak pernah terlepas dari bagaimana perilaku penggunanya, keberhasilan dari penerapan suatu sistem informasi tidak hanya ditentukan oleh bagaimana sistem tersebut bisa beroperasi dengan baik, tetapi juga ditentukan oleh tingkat penerimaan individu dalam menerapkan suatu sistem teknologi yang baru. Penerimaan suatu teknologi informasi yang baru dapat dihubungkan dengan menggunakan Technology Accepted Model (TAM). Davis, dalam Jogiyanto 2007 "Technology Accepted Model (TAM) merupakan model yang digunakan untuk memprediksi penerimaan individu terhadap teknologi berdasarkan dua variabel, yaitu persepsi kebermanfaatan (perceived usefulness) dan persepsi kemudahan penggunaan (perceived ease of use)". Persepsi kebermanfaatan, persepsi kemudahan dan persepsi kepuasan wajib pajak ini dapat dihubungkan dengan model penerimaan teknologi atau Technology Accepted Model (TAM), dimana TAM merupakan salah satu teori yang menjelaskan tentang penggunaan sistem teknologi informasi terhadap individual dan juga TAM dapat membantu pengguna dalam menilai dan memberikan pandangan dengan penggunaan sistem $e$ filing. Penerimaan individu terhadap sistem e-filing ini tidak terlepas dari persepsi penggunanya. Menurut Walgito (2010) persepsi merupakan suatu proses yang didahului oleh proses penginderaan, yaitu merupakan proses diterimanya stimulus oleh individu melalui alat indera atau juga disebut proses sensoris, namun proses tersebut tidak berhenti begitu saja, melainkan stimulus itu diteruskan dan proses selanjutnya merupakan proses persepsi. Lebih lanjut menurut Suharman (2005:23) "persepsi merupakan suatu proses menginterpretasikan atau menafsirkan informasi yang diperoleh melalui sistem alat indera manusia". Pada tahun 2016 pemerintah mulai mewajibkan penggunaan sistem e-filing ini pada wajib pajak yang berstatus sebagai pegawai negeri sipil dengan tujuan untuk 
mempermudah wajib pajak dalam pelaporan Surat Pemberitahuan (SPT) Tahunannya

(www.pajak.go.id/article2016).

Penelitian ini difokuskan pada wajib pajak orang pribadi di Universitas Pendidikan Ganesha (UNDIKSHA). Universitas Pendidikan Ganesha (UNDIKSHA) merupakan perguruan tinggi negeri yang mencetak sumber daya manusia dalam bidang kependidikan dan non kependidikan. Universitas Pendidikan Ganesha (UNDIKSHA) memiliki jumlah tenaga kerja sebanyak 1.100 orang yang terdiri dari dosen yang berjumlah 599 orang dan pegawai yang berjumlah 501 orang. Tenaga kerja yang berstatus sebagai pegawai negeri sipil di Universitas Pendidikan Ganesha berjumlah 680 orang yang terdiri dari dosen berjumlah 433 orang dan pegawai berjumlah 247 orang. Sebagai perguruan tinggi negeri tentunya Universitas Pendidikan Ganesha (UNDIKSHA) mendukung kebijakan pemerintah dalam penggunaan sistem $e$ filing. Wajib pajak yang berstatus sebagai pegawai negeri sipil wajib melaporkan Surat pemberitahuan (SPT) Tahunan berjumlah 680 orang di Universitas Pendidikan Ganesha dan telah menggunakan sistem e-filing dalam pelaporan Surat Pemberitahuan (SPT) Tahunannya, namun masih banyak wajib pajak belum mengerti sepenuhnya cara melaporkan Surat Pemberitahuan (SPT) dengan sistem e-filing dan memilih untuk datang ke Kantor Pelayanan Pajak (KPP). Padahal penggunaan e-filing ini dapat memberikan manfaat bagi wajib pajak karena wajib pajak dapat melaporkan Surat Pemberitahuan (SPT) Tahunannya dimana saja dan kapan saja, wajib pajak tidak lagi datang dan mengantri di Kantor Pelayanan Pajak (KPP) untuk melaporkan Surat Pemberitahuan (SPT) Tahunannya. Penggunaan sistem e-filing dalam pelaporan Surat Pemberitahuan (SPT) Tahunan ini memunculkan persepsi dari wajib pajak khususnya pada wajib pajak di Universitas Pendidikan Ganesha (UNDIKSHA), ada pihak yang memiliki anggapan sulit dan tidak bermanfaat, sedangkan ada pihak yang beranggapan mudah dan bermanfaat sehingga pengguna merasa puas. Berdasarkan permasalahan tersebut, maka peneliti tertarik untuk melakukan penelitian dengan judul "Persepsi Kebermanfaatan, Kemudahan dan Kepuasan Wajib Pajak Orang Pribadi Dalam Penggunaan E-filing Sebagai Sarana Pelaporan SPT Tahunan Secara Elektronik (Studi Pada Dosen dan Pegawai Universitas Pendidikan Ganesha Tahun 2017)".

Berdasarkan latar belakang di atas, maka adapun rumusan masalah dalam penelitian ini adalah bagaimana persepsi kebermanfaatan, bagaimana persepsi kemudahan dan bagaimana persepsi kepuasan wajib pajak orang pribadi dalam penggunaan sistem e-filing sebagai pelaporan SPT Tahunan secara elektronik (studi pada dosen dan pegawai Universitas Pendidikan Ganesha Tahun 2017). Sesuai dengan rumusan masalah yang dirumuskan maka tujuan dalam penelitian ini yaitu untuk mengetahui persepsi kebermanfaatan, persepsi kemudahan dan persepsi kepuasan wajib pajak orang pribadi dalam penggunaan sistem e-filing sebagai pelaporan SPT Tahunan secara elektronik (studi pada dosen dan pegawai Universitas Pendidikan Ganesha Tahun 2017).

\section{METODE}

Jenis penelitian yang digunakan dalam penelitian ini adalah penelitian deskriptif. Penelitian deskriptif adalah penelitian yang bertujuan untuk memberikan atau menjabarkan suatu keadaan atau fenomena yang terjadi saat ini dengan menggunakan prosedur ilmiah untuk menjawab masalah secara aktual (Sugiyono,2011). Penelitian deskriptif dilakukan untuk memperoleh informasi mengenai persepsi kebermanfaatan, persepsi kemudahan dan persepsi kepuasan wajib pajak dalam penggunaan e-filing pada pelaporan Surat Pemberitahuan (SPT) Tahunan.

Jenis data dalam penelitian ini adalah data kuantitatif berupa angkaangka jawaban dari responden mengenai kuesioner persepsi kebermanfaatan, persepsi kemudahan dan persepsi kepuasan wajib pajak dalam penggunaan sistem e-filing dalam pelaporan Surat 
Pemberitahuan (SPT) Tahunan. Adapun sumber data yang dipergunakan dalam penelitian ini adalah data primer dan data skunder. Data primer dalam penelitian ini berupa angka-angka jawaban dari responden mengenai kuesioner persepsi kebermanfaatan, persepsi kemudahan dan persepsi kepuasan wajib pajak orang pribadi dalam penggunaan sistem e-filing sebagai sarana pelaporan Surat Pemberitahuan (SPT) Tahunan. Data sekunder dalam penelitian ini berupa data dokumen nama, jumlah dosen dan pegawai di Universitas Pendidikan Ganesha Tahun 2017.

Populasi adalah keseluruhan subjek penelitian (Arikunto, 2010), populasi dalam penelitian ini adalah dosen dan pegawai pada Universitas Pendidikan Ganesha yang telah berstatus sebagai pegawai negeri sipil dan wajib melaporkan Surat Pemberitahuan (SPT) Tahunan dengan sistem e-filing. Adapun populasi pada penelitian ini berjumlah 680 orang yang terdiri dari dosen berjumlah 433 orang dan pegawai berjumlah 247 orang. Sampel pada penelitian ini adalah dosen dan pegawai pada Universitas Pendidikan Ganesha yang wajib melaporkan Surat Pemberitahuan (SPT) Tahunan dan terdaftar menggunakan sistem e-filing, untuk menentukan jumlah sampel dalam penelitian ini, yaitu dengan menggunakan rumus Slovin:

Formula Slovin (Husein, 2002)

$$
\begin{aligned}
& n=\frac{N}{1+N e^{2}} \\
& \text { Keterangan: } \\
& \mathrm{n}=\text { ukuran sampel } \\
& \mathrm{N}=\text { ukuran populasi } \\
& \mathrm{e}=\text { persen kelonggaran } \\
& \quad \text { ketidaktelitian karena } \\
& \text { kesalahan pengambilan } \\
& \text { sampel yang masih dapat } \\
& \text { ditolerir atau diinginkan } \\
& \mathrm{n}= 680 / 1+680 .\left(0.1^{2}\right) \\
&= 680 / 7,8 \\
& \mathrm{n}= 87,17 \text { dibulatkan menjadi } 87
\end{aligned}
$$

Hasil dari pengolahan data populasi di atas dapat disimpulkan bahwa untuk jumlah sampel pada penelitian ini adalah berjumlah 87 orang. Adapun teknik pengambilan sampel pada penelitian ini yaitu dengan menggunakan purposive proportional random sampling. Purposive proportional random sampling adalah

\begin{tabular}{|c|c|c|c|}
\hline $\begin{array}{c}\text { Nama } \\
\text { Kriteria }\end{array}$ & Populasi & Sampel & \\
\hline Dosen & 433 orang & $\begin{array}{l}\mathrm{n}=\frac{43 \mathrm{a}}{650} \mathrm{x} \quad 87 \\
55,39 \\
\text { (dibulatkan } \\
\text { menjadi 55) }\end{array}$ & $=$ \\
\hline Pegawai & 247 orang & $\begin{array}{l}\mathrm{n}=\frac{247}{6,90} \mathrm{x} \quad 87 \\
31,60 \\
\text { (dibulatkan } \\
\text { menjadi 32) }\end{array}$ & $=$ \\
\hline
\end{tabular}
penentuan sampel dengan pertimbangan tertentu. Kriteria yang digunakan dalam penelitian ini yaitu dosen dan pegawai pada Universitas Pendidikan Ganesha yang berstatus sebagai pegawai negeri sipil dan menggunakan e-filing. Jumlah sampel dalam penelitian ini dapat dilihat pada tabel 1 berikut ini.

Tabel 1. Jumlah Sampel Dosen dan Pegawai Pengguna Sistem EFiling

Dalam melakukan penelitian, peneliti menggunakan metode dokumentasi dan kuesioner. Metode dokumentasi digunakan untuk memperoleh nama-nama pegawai dan dosen yang menggunakan $e$ filing dan kuesioner digunakan untuk memperoleh data tentang persepsi kebermanfaatan, persepsi kemudahan dan persepsi kepuasan wajib pajak dalam penggunaan e-filing sebagai sarana pelaporan SPT Tahunan secara elektronik. Kategori penskoran kuesioner persepsi kebermanfaatan, persepsi kemudahan dan persepsi kepuasan wajib pajak dalam penggunaan sistem e-filing dengan skala likert. Skala likert digunakan untuk mengkur sikap, pendapat, dan persepsi seseorang atau sekelompok orang tentang fenomena sosial (Sugiyono, 2013). Pengukuran variabel menggunakan skala likert dengan lima alternatif jawaban masing-masing diberi skor, yaitu skor 5 =sangat setuju (SS), skor $4=$ setuju (S), skor 3 = kurang setuju (KS), skor 2= tidak setuju (TS), dan skor 1 = sangat tidak setuju (STS).

Teknik analisis data yang digunakan dalam penelitian ini adalah analisis deskriptif. Analisis deskriptif digunakan 
untuk mendeskripsikan persepsi kebermanfaatan, persepsi kemudahan dan persepsi kepuasan wajib pajak dalam penggunaan $e$-filing. Penentuan rentang skala dapat ditetapkan dengan hal-hal berikut, rentang jawaban menggunakan skala likert 1 sampai 5, jumlah skor tertinggi (positif) adalah jumlah pernyataan dikali skala tertinggi, jumlah skor terendah (negatif) adalah jumlah pertanyaan dikali skala terendah (Sugiyono,2011).

Dari langkah-langkah di atas maka kriteria persepsi kebermanfaatan e-filing dapat dilihat pada tabel 2 berikut.

Tabel 2. Kriteria total skor persepsi kebermanfatan dalam penggunaan e-filing dari aspek kegunaan

\begin{tabular}{cl} 
Rentang Skor & \multicolumn{1}{c}{ Kategori } \\
\hline $2.192,4-2.610$ & Sangat Setuju \\
$1.774,8-2.192,3$ & Setuju \\
$1.357,2-1.774,7$ & Kurang Setuju \\
$939,6-1357,1$ & Tidak Setuju \\
$552-939,5$ & Sangat Tidak Setuju \\
\hline
\end{tabular}

Berdasarkan tabel 2 di atas, kriteria persepsi kebermanfaatan dengan total skor 2.192,4 - 2.610, maka persepsi wajib pajak dalam penggunaan e-filing sebagai sarana pelaporan SPT Tahunan secara elektronik ditinjau dari aspek kegunaan dinyatakan sangat setuju. Kriteria persepsi dengan total skor 1.774,8 - 2.192,3 dinyatakan setuju. Kriteria persepsi dengan total skor 1.357,2 - 1.774,7 dinyatakan kurang setuju. Kriteria persepsi dengan total skor 939,6 - 1357,1 dinyatakan tidak setuju, dan jika kriteria persepsi dengan total skor 552 - 939,5, dinyatakan sangat tidak setuju.

Tabel 3. Kriteria total skor persepsi kebermanfatan dalam penggunaan e-filing dari aspek efektivitas sistem

\begin{tabular}{cl}
\hline Rentang Skor & \multicolumn{1}{c}{ Kategori } \\
\hline $1.827-2.175$ & Sangat Setuju \\
$1.479-1.826$ & Setuju \\
$1.131-1.478$ & Kurang Setuju \\
$783-1130$ & Tidak Setuju \\
$435-782$ & Sangat Tidak Setuju \\
\hline
\end{tabular}

Berdasarkan tabel 3 di atas, kriteria persepsi kebermanfaatan dengan total skor 1.827-2.175, maka persepsi wajib pajak dalam penggunaan e-filing sebagai sarana pelaporan SPT Tahunan secara elektronik ditinjau dari aspek efektivitas sistem dinyatakan sangat setuju. Kriteria persepsi dengan total skor $1.479-1.826$ dinyatakan setuju. Kriteria persepsi dengan total skor 1.131-1.478 dinyatakan kurang setuju. Kriteria persepsi dengan total skor 1.131-783 dinyatakan tidak setuju, dan jika kriteria persepsi dengan total skor 435-782, dinyatakan sangat tidak setuju.

Tabel 4. Kriteria total skor persepsi kebermanfaatan wajib pajak dalam penggunaan e-filing

\begin{tabular}{cl}
\hline Rentang Skor & \multicolumn{1}{c}{ Kategori } \\
\hline $3.654-4.350$ & Sangat Setuju \\
$2.958-3.653$ & Setuju \\
$2.262-2.957$ & Kurang Setuju \\
$1.566-2.261$ & Tidak Setuju \\
$870-1.565$ & Sangat Tidak Setuju \\
\hline
\end{tabular}

Berdasarkan tabel 4 di atas, kriteria persepsi kebermanfaatan dengan total skor 3.654 - 4.350, maka persepsi wajib pajak dalam penggunaan e-filing sebagai sarana pelaporan SPT Tahunan secara elektronik dinyatakan sangat setuju. Kriteria persepsi dengan total skor 2.958 3.653 dinyatakan setuju. Kriteria persepsi dengan total skor 2.262 - 2.957 dinyatakan kurang setuju. Kriteria persepsi dengan total skor $1.566-2.261$ dinyatakan tidak setuju, dan jika kriteria persepsi dengan total skor $870-1.565$, dinyatakan sangat tidak setuju.

Tabel 5. Kriteria total skor persepsi kemudahan wajib pajak dalam penggunaan e-filing ditinjau dari aspek mudah dan fleksibel

\begin{tabular}{cl}
\hline Rentang Skor & \multicolumn{1}{c}{ Kategori } \\
\hline $1.461,6-1.740$ & Sangat Setuju \\
$1.183,2-1.461,5$ & Setuju \\
$904,8-1183,1$ & Kurang Setuju \\
$626,4-904,7$ & Tidak Setuju \\
$348-626,3$ & Sangat Tidak Setuju \\
\hline
\end{tabular}

Berdasarkan tabel 5 di atas, kriteria persepsi kemudahan dengan total skor $1.461,6-1.740$, maka persepsi kemudahan wajib pajak dalam 
penggunaan e-filing sebagai sarana pelaporan SPT Tahunan secara elektronik ditinjau dari aspek mudah dan fleksibel dinyatakan sangat setuju. Kriteria persepsi dengan total skor 1.183,2 $1.461,5$ dinyatakan setuju. Kriteria persepsi dengan total skor 904,8- 1183,1 dinyatakan kurang setuju. Kriteria persepsi dengan total skor 626,4- 904,7dinyatakan tidak setuju, dan jika kriteria persepsi dengan total skor 348 - 626,3, dinyatakan sangat tidak setuju.

Tabel 6. Kriteria total skor persepsi kemudahan wajib pajak dalam penggunaan e-filing

\begin{tabular}{cl}
\hline Rentang Skor & \multicolumn{1}{c}{ Kategori } \\
\hline $2.923,2-3.480$ & Sangat Setuju \\
$2.366,4-2.923,1$ & Setuju \\
$1.809,6-2.366,3$ & Kurang Setuju \\
$1.252,8-1.809,6$ & Tidak Setuju \\
$696-1252,7$ & Sangat Tidak Setuju
\end{tabular}

Berdasarkan tabel 6 di atas, kriteria persepsi kemudahan dengan total skor 2.923,2 - 3.480, maka persepsi kemudahan wajib pajak dalam penggunaan e-filing sebagai sarana pelaporan SPT Tahunan secara elektronik dinyatakan sangat setuju. Kriteria persepsi dengan total skor 2.366,4 $2.923,1$ dinyatakan setuju. Kriteria persepsi dengan total skor 2.366,4 $2.923,1$ dinyatakan kurang setuju. Kriteria persepsi dengan total skor 1.252,8 1.809,6 dinyatakan tidak setuju, dan jika kriteria persepsi dengan total skor 696 1252,7 , dinyatakan sangat tidak setuju.

Tabel 7. Kriteria total skor persepsi kepuasan wajib pajak dalam penggunaan e-filing ditinjau dari aspek efisien

\begin{tabular}{cl}
\hline Rentang Skor & \multicolumn{1}{c}{ Kategori } \\
\hline $1.096,2-1.305$ & Sangat Setuju \\
$887,4-1.096,1$ & Setuju \\
$678,6-887,3$ & Kurang Setuju \\
$469,8-678,5$ & Tidak Setuju \\
$261-469,8$ & Sangat Tidak Setuju \\
\hline
\end{tabular}

Berdasarkan tabel 7 di atas, kriteria persepsi kepuasan dengan total skor 1.096,2- 1.305, maka persepsi kemudahan wajib pajak dalam penggunaan e-filing sebagai sarana pelaporan SPT Tahunan secara elektronik ditinjau dari aspek efisien dinyatakan sangat setuju. Kriteria persepsi dengan total skor 887,4 - 1.096,1 dinyatakan setuju. Kriteria persepsi dengan total skor 678,6- 887,3dinyatakan kurang setuju. Kriteria persepsi dengan total skor 469,8678,5 dinyatakan tidak setuju, dan jika kriteria persepsi dengan total skor 261 469,8 , maka persepsi kemudahan wajib pajak orang pribadi dalam penggunaan sistem e-filing sebagai sarana pelaporan SPT Tahunan secara elektronik dinyatakan sangat tidak setuju.

Tabel 8. Kriteria total skor persepsi kepuasan wajib pajak dalam penggunaan e-filing ditinjau dari aspek rasa puas

\begin{tabular}{cl}
\hline Rentang Skor & \multicolumn{1}{c}{ Kategori } \\
\hline $1.461,6-1.740$ & Sangat Setuju \\
$1.183,2-1.461,5$ & Setuju \\
$904,8-1183,1$ & Kurang Setuju \\
$626,4-904,7$ & Tidak Setuju \\
$348-626,3$ & Sangat Tidak Setuju
\end{tabular}

Berdasarkan tabel 8 di atas, kriteria persepsi kepuasan dengan total skor $1.461,6-1.740$, maka persepsi kemudahan wajib pajak dalam penggunaan e-filing sebagai sarana pelaporan SPT Tahunan secara elektronik ditinjau dari aspek rasa puas dinyatakan sangat setuju. Kriteria persepsi dengan total skor 1.183,2 - 1.461,5 dinyatakan setuju. Kriteria persepsi dengan total skor 904,8 - 1183,1 dinyatakan kurang setuju. Kriteria persepsi dengan total skor 626,4 904,7 dinyatakan tidak setuju, dan jika kriteria persepsi dengan total skor 348 626,3 , dinyatakan sangat tidak setuju.

Tabel 9. Kriteria total skor persepsi kepuasan wajib pajak dalam penggunaan e-filing

\begin{tabular}{|c|c|}
\hline Rentang Skor & Kategori \\
\hline $2.557,8-3.045$ & Sangat Setuju \\
\hline $2.070,6-2.557,7$ & Setuju \\
\hline $1.583,4-2.070,5$ & Kurang Setuju \\
\hline $1.096,2-1.583,3$ & Tidak Setuju \\
\hline $609-1.092,1$ & Sangat Tidak Setuju \\
\hline
\end{tabular}

Berdasarkan tabel 9 di atas, kriteria persepsi kepuasan dengan total skor $2.557,8-3.045$, maka persepsi 
kemudahan wajib pajak dalam penggunaan e-filing sebagai sarana pelaporan SPT Tahunan secara elektronik dinyatakan sangat setuju. Kriteria persepsi dengan total skor 2.070,6 - 2.557,7 dinyatakan setuju. Kriteria persepsi dengan total skor 1.583,4 - 2.070,5 dinyatakan kurang setuju. Kriteria persepsi dengan total skor 1.096,2 - 1.583,3 dinyatakan tidak setuju, dan jika kriteria persepsi dengan total skor $609-1.092,1$ dinyatakan sangat tidak setuju

\section{HASIL DAN PEMBAHASAN Hasil}

Berdasarkan perhitungan yang dilakukan dengan perbandingan skala interval yang diperoleh, maka dapat

wajib pajak dalam penggunaan e-filing sebagai pelaporan SPT Tahunan secara elektronik sebagai berikut.

Tabel 10. Hasil analisis data persepsi kebermanfaatan wajib pajak dalam penggunaan e-filing

\begin{tabular}{|c|c|c|c|}
\hline Dimensi & Skor & Skala Interval & Kategori \\
\hline Kegunaan & 2542 & $2192,4-2610$ & $\begin{array}{l}\text { Sangat } \\
\text { Setuju }\end{array}$ \\
\hline Efektivitas & 1660 & $1479-1826$ & Setuju \\
\hline Total & 4202 & $3654-4350$ & $\begin{array}{l}\text { Sangat } \\
\text { Setuju }\end{array}$ \\
\hline
\end{tabular}

Berdasarkan tabel 10 di atas, dapat dijelaskan bahwa persepsi kebermanfaatan pada aspek kegunaan memiliki skor total 2542. Jika dibandingkan dengan kriteria persepsi kebermanfaatan, maka persepsi kebermanfaatan sistem e-filing pada aspek kegunaan masuk dalam range skor 2192,4 - 2610 dengan kriteria Sangat Setuju. Persepsi kebermanfaatan pada aspek efektivitas sistem memiliki skor total 1660. Jika dibandingkan dengan kriteria persepsi kebermanfaatan, maka persepsi kebermanfaatan sistem e-filing pada aspek kegunaan masuk dalam range skor 1479 - 1826 dengan kriteria Setuju. Persepsi kebermanfaatan wajib pajak atas sistem e-filing memiliki skor total 4202. Jika dibandingkan dengan kriteria persepsi kebermanfaatan, maka persepsi kebermanfaatan wajib pajak orang pribadi (dosen dan pegawai Universitas Pendidikan Ganesha Tahun 2017) secara total masuk dalam range skor 3654 - 4350 dengan kriteria Sangat Setuju.

Tabel 11. Hasil analisis data persepsi kemudahan wajib pajak dalam penggunaan e-filing

\begin{tabular}{lccc}
\hline Dimensi & Skor & Skala Interval & Kategori \\
\hline Mudah & 1430 & $1183,2-$ & Setuju \\
Fleksibel & 1451 & 1461,5 & Setuju \\
& & $1183,2-$ & \\
& & 1461,5 & \\
Total & 2881 & $2366,4-$ & Setuju \\
& & 2923,1 & \\
\hline
\end{tabular}

Berdasarkan tabel 11 di atas, dapat dijelaskan bahwa persepsi kemudahan

1430. Jika dibandingkan dengan kriteria persepsi kemudahan, maka persepsi kemudahan sistem e-filing pada aspek mudah masuk dalam range skor 1183,2 1461,5 dengan kriteria Setuju. Persepsi kemudahan pada aspek fleksibel memiliki skor total 1451. Jika dibandingkan dengan kriteria persepsi kemudahan, maka persepsı kemuaanan sistem e-tIIIng paaa aspek fleksibel masuk dalam range skor 1183,2 - 1461,5 dengan kriteria Setuju. Persepsi kemudahan wajib pajak atas sistem e-filing memiliki skor total 2881. Jika dibandingkan dengan kriteria persepsi kemudahan, maka persepsi kemudahan wajib pajak orang pribadi (dosen dan pegawai Universitas Pendidikan Ganesha Tahun 2017) secara total masuk dalam range skor 2366,4 - 2923,1 dengan kriteria Setuju.

Tabel 12. Hasil analisis data persepsi kepuasan wajib pajak dalam penggunaan e-filing

\begin{tabular}{lccc} 
& \multicolumn{2}{c}{ penggunaan e-filing } & \\
\cline { 4 - 5 } Dimensi & Skor & Skala Interval & Kategori \\
\hline Efisiensi & 1.112 & $1.096,2-$ & Sangat \\
& & 1.305 & Setuju \\
Rasa & 1.453 & & Setuju \\
Puas & & $1.183,2-$ & \\
& & $1.461,5$ & \\
Total & 2.565 & $2557,8-3045$ & Sangat \\
& & & Setuju \\
\hline
\end{tabular}

Berdasarkan tabel 12 di atas, dapat dijelaskan bahwa persepsi kepuasan pada aspek efisiensi memiliki skor total 1112. 
Jika dibandingkan dengan kriteria persepsi kepuasan, maka persepsi kepuasan sistem e-filing pada aspek efisiensi masuk dalam range skor 1096,2- 1305 dengan kriteria Sangat Setuju. Persepsi kepuasan pada aspek rasa puas memiliki skor total 1453. Jika dibandingkan dengan kriteria persepsi kepuasan, maka persepsi kepuasan sistem e-filing pada aspek rasa puas masuk dalam range skor 1183,2 1461,5 dengan kriteria Setuju. Persepsi kepuasan wajib pajak atas sistem e-filing memiliki skor total 2565. Jika dibandingkan dengan kriteria persepsi kepuasan, maka persepsi kepuasan wajib pajak orang pribadi (dosen dan pegawai Universitas Pendidikan Ganesha Tahun 2017) secara total masuk dalam range skor 2557,8 - 3045 dengan kriteria Sangat Setuju.

\section{Pembahasan}

Berdasarkan hasil penelitian, penggunaan sistem e-filing dalam melakukan pelaporan Surat Pemberitahuan (SPT) memunculkan persepsi bagi penggunanya, termasuk dosen dan pegawai di Universitas Pendidikan Ganesha Tahun 2017. Persepsi wajib pajak atas penggunaan $e$ filing juga sangat penting bagi keberhasilan dari dijalankannya sistem efiling dalam pelaporan Surat Pemberitahuan (SPT), hal ini sesuai dengan pendapat Jogiyanto (2007) yang menyatakan bahwa keberhasilan dari dijalankannya suatu sistem informasi tidak terlepas dari perilaku penggunanya.

Wajib pajak dosen dan pegawai di Universitas Pendidikan Ganesha Tahun 2017 memiliki persepsi sangat setuju bahwa sistem e-filing bermanfaat dalam melakukan pelaporan SPT secara elektronik ditinjau dari aspek kegunaannya. Temuan ini membuktikan bahwa wajib pajak dosen dan pegawai di Universitas Pendidikan Ganesha merasakan manfaat dari penggunaan $e$ filing dalam melakukan pelaporan Surat Pemberitahuan (SPT) yaitu sistem e-filing dapat membuat pelaporan Surat Pemberitahuan (SPT) menjadi lebih cepat dan tepat waktu. Penggunaan e-filing dapat memudahkan wajib pajak dalam pelaporan Surat Pemberitahuan (SPT) karena tidak perlu datang ke Kantor Pelayanan Pajak, selain itu wajib pajak juga dapat menghemat biaya dan energi dalam melakukan pelaporan Surat Pemberitahuan (SPT) menggunakan $e$ filing.

Wajib pajak dosen dan pegawai di Universitas Pendidikan Ganesha Tahun 2017 memiliki persepsi setuju bahwa sistem e-filing bermanfaat dalam melakukan pelaporan SPT secara elektronik ditinjau dari aspek efektivitas sistem. Hal ini menunjukkan bahwa penggunaan sistem e-filing mampu meningkatkan efektivitas dalam pelaporan Surat Pemberitahuan (SPT) karena dapat dilakukan dimana saja dan kapan saja, selain itu penggunaan e-filing juga dapat memudahkan wajib pajak untuk memperoleh bukti dari pelaporan Surat Pemberitahuan (SPT). Wajib pajak dosen dan pegawai Universitas Pendidikan Ganesha memiliki persepsi sangat setuju bahwa sistem e-filing sangat bermanfaat dilihat dari skor total pada persepsi kebermanfaatan yaitu sebesar 4202 dan masuk pada kriteria sangat setuju. Temuan ini sesuai dengan pendapat Jogiyanto (2007) yang menyatakan bahwa persepsi kebermanfaatan penggunaan merupakan sejauh mana seseorang percaya bahwa menggunakan suatu teknologi akan meningkatkan kinerja dari pekerjaannya.

Berdasarkan hasil penelitian yang dilakukan, persepsi kemudahan wajib pajak khususnya dosen dan pegawai di Universitas Pendidikan Ganesha setuju bahwa sistem e-filing merupakan sistem yang mudah untuk digunakan ditinjau dari aspek mudah, hal ini menunjukkan bahwa menurut dosen dan pegawai sistem $e$ filing mudah untuk dipelajari, sehingga wajib pajak dapat mengoperasikan sistem e-filing tanpa harus berkonsultasi secara terus menerus dengan petugas pajak dalam melakukan pelaporan Surat Pemberitahuan (SPT). Penggunaan efiling dapat menawarkan kontrol yang memadai yaitu dapat meningkatkan keamanan data dan tampilan sistem $e$ filing mudah untuk dipahami.

Wajib pajak dosen dan pegawai di 
Universitas Pendidikan Ganesha Tahun 2017 memiliki persepsi setuju bahwa sistem e-filing merupakan sistem yang mudah untuk digunakan ditinjau dari aspek fleksibel. Hal ini menunjukkan bahwa wajib pajak dosen dan pegawai merasakan sistem e-filing adalah sistem yang fleksibel sehingga pengguna dapat dengan mudah untuk mempelajari dan mengoperasikan sistem tersebut. Wajib pajak juga tidak merasa rumit ketika menggunakan e-filing dalam melakukan pelaporan Surat Pemberitahuan (SPT). Wajib pajak dosen dan pegawai Universitas Pendidikan Ganesha Tahun 2017 memiliki persepsi setuju bahwa sistem e-filing mudah untuk digunakan dilihat dari skor total pada persepsi kemudahan yaitu sebesar 2881 dan masuk pada kriteria setuju. Temuan ini sesuai dengan pendapat Jogiyanto (2007) yang menyatakan bahwa persepsi tentang kemudahan penggunaan sebuah teknologi didefinisikan sebagai sejauh mana seseorang percaya bahwa menggunakan suatu teknologi akan bebas dari usaha, dan merupakan suatu kepercayaan tentang proses pengambilan keputusan.

Berdasarkan hasil penelitian, persepsi kepuasan wajib pajak khususnya dosen dan pegawai di Universitas Pendidikan Ganesha Tahun 2017 sangat setuju bahwa sistem e-filing merupakan sistem yang dapat memberikan kepuasan ditinjau dari aspek efisiensi sistem, hal ini menunjukkan bahwa menurut dosen dan pegawai sistem e-filing memiliki tingkat efisiensi yang tinggi karena dengan melakukan pelaporan Surat Pemberitahuan (SPT) dengan e-filing pengguna dapat mengefisiensikan waktu dan biaya. Selain itu sistem e-filing juga memiliki tingkat efektivitas yang tinggi sehingga dapat memberikan kepuasan kepada penggunanya.

Wajib pajak dosen dan pegawai di Universitas Pendidikan Ganesha Tahun 2017 memiliki persepsi setuju bahwa sistem e-filing merupakan sistem yang dapat memberikan kepuasan pada pengguna ditinjau dari aspek rasa puas. Hal ini menunjukkan bahwa wajib pajak dosen dan pegawai merasakan sistem $e$ filing dapat memberikan kepuasan bagi pengguna sehingga wajib pajak memiliki pengalaman yang menyenangkan dalam menggunakan e-filing dan merasa bangga dapat menggunakan sistem e-filing dalam pelaporan Surat Pemberitahuan (SPT). Wajib pajak dosen dan pegawai Universitas Pendidikan Ganesha Tahun 2017 memiliki persepsi setuju bahwa sistem e-filing dapat memberikan kepuasan, hal ini dapat dilihat dari skor total pada persepsi kepuasan yaitu sebesar 2565 dan masuk pada kriteria sangat setuju. Temuan ini sesuai dengan pendapat Soddon and Kiev (dalam Jogiyanto, 2007) yang menyatakan bahwa kepuasan pengguna merupakan perasaan bersih dari senang atau tidak senang dalam menerima sistem informasi dari keseluruhan manfaat dan kemudahan yang diharapkan seseorang dimana perasaan tersebut dihasilkan dari interaksi dengan sistem informasi. Hasil dari penelitian ini sesuai dengan penelitian Citra (2014) bahwa penggunaan e-filing memunculkan persepsi dari penggunanya, jika pengguna memiliki persepsi bahwa sistem tersebut bermanfaat, mudah digunakan dan dapat memberikan kepuasan berarti sistem tersebut telah berhasil untuk dijalankan.

\section{PENUTUP \\ Simpulan}

Berdasarkan hasil penelitian dan pembahasan, maka dapat di simpulkan bahwa persepsi kebermanfaatan wajib pajak orang pribadi dalam penggunaan $e$ filing sebagai sarana pelaporan SPT Tahunan secara elektronik (studi pada dosen dan pegawai Universitas Pendidikan Ganesha Tahun 2017) yaitu sistem e-filing sangat bermanfaat dalam melakukan pelaporan SPT Tahunan. Hal ini dapat dilihat dari perolehan pada masing-masing aspek, yaitu aspek kegunaan memiliki kriteria sangat bermanfaat (2542), aspek efektivitas memiliki kriteria kriteria bermanfaat (1660) dan secara keseluruhan persepsi kebermanfaatan memiliki kriteria sangat bermanfaat (4202). Persepsi kemudahan wajib pajak orang pribadi dalam penggunaan e-filing sebagai sarana pelaporan SPT Tahunan secara elektronik 
(studi pada dosen dan pegawai Universitas Pendidikan Ganesha Tahun 2017) yaitu sistem e-filing mudah untuk digunakan dalam melakukan pelaporan SPT Tahunan. Hal ini dapat dilihat dari perolehan pada masing-masing aspek, yaitu aspek mudah memiliki kriteria mudah (1430), aspek fleksibel memiliki kriteria mudah (1451) dan secara keseluruhan persepsi kemudahan penggunaan e-filing memiliki kriteria mudah (2881), dan persepsi kepuasan wajib pajak orang pribadi dalam penggunaan e-filing sebagai sarana pelaporan SPT Tahunan secara elektronik (studi pada dosen dan pegawai Universitas Pendidikan Ganesha Tahun 2017) yaitu sangat puas. Hal ini dapat dilihat dari perolehan masing-masing aspek, yaitu aspek efisiensi memiliki kriteria sangat puas (1112), aspek rasa puas memiliki kriteria puas (1453) dan secara keseluruhan persepsi kepuasan wajib pajak dalam penggunaan e-filing memiliki kriteria sangat puas (2565).

\section{Saran}

Berdasarkan simpulan hasil penelitian dan pembahasan tersebut, maka dalam penelitian ini dapat dikemukakan saran yaitu bagi Bagi peneliti selanjutnya yang tertarik untuk mengkaji aspek yang serupa mengenai persepsi kebermanfaatan, kemudahan dan kepuasan wajib pajak dalam penggunaan sistem e-filing sebagai sarana pelaporan SPT Tahunan secara elektronik diharapkan untuk mengembangkan penelitian ini dengan menggunakan populasi dan sampel yang lebih luas, tidak hanya pada wajib pajak orang pribadi di Universitas Pendidikan Ganesha, tetapi juga pada wajib pajak lainnya agar hasil penelitian lebih teruji keandalannya.

\section{DAFTAR PUSTAKA}

Arikunto, Suharsimi. 2010. Prosedur Penelitian: Suatu Pendekatan Praktik. (Edisi Revisi). Jakarta: Rineka Cipta.

Citra, Nurul Noviandani. 2014. Pengaruh Persepsi Persepsi
Penggunaandan Kepuasan Wajib Pajak Terhadap Penggunaan EFiling bagi Wajib Pajak Di Yogyakarta. Skripsi tidak diterbitkan. Fakultas Ekonomi Universitas Negeri Yogyakarta.

Husein, Umar. 2002. Metode Riset Bisnis. Jakarta: PT.Gramedia.

Jogiyanto, Hartono. 2007. Sistem Informasi Keperilakuan. Yogyakarta: CV Andi Offset.

Mardiasmo. 2011. Perpajakan. Edisi Revisi tahun 2011. Yogyakarta: CV Andi Offset

Pandiangan, Liberty. 2014. Administrasi Perpajakan. Jakarta: Erlangga.

Resmi, Siti. 2007. Perpajakan: Teori dan Kasus. Jakarta: Salemba Empat. 2011. Perpajakan Teori dan Kasus Edisi 6 Buku 1, Jakarta : Salemba Empat.

Sari, Diana. 2013. Konsep Dasar Perpajakan. Bandung: Refika Aditama.

Suharman. 2005. Psikologi Kognitif. Surabaya:Srikandi.

Sugiyono. 2011. Metode Penelitian Administratif. Bandung : Alfabeta.

---------. 2013. Metode Penelitian Kuantitatif, Kualitatif dan $R \& D$, Bandung : Alfabeta.

Walgito, Bimo. 2010. Pengantar Psikologi Umum. Yogyakarta: CV Andi. 